\title{
Odour pollution assessment through indirect methods based on the monitoring of technological parameters - case study
}

\author{
ELENA BUCUR , VALERIU DANCIULESCU , GHEORGHITA TANASE , CAROL BLAZIU \\ LEHR , ANDREI VASILE *
}

National Research and Development Institute for Industrial Ecology ECOIND Bucharest, 71-73 Drumul Podul Dambovitei, 060652, Bucharest, Romania

*corresponding author (e-mail): poluare.aer@incdecoind.ro

The odours in the ambient air, through the discomfort that they induce, represent an actual problem for the communities located nearby companies with technological processes that emit in the air different strong and unpleasant odorous substances.

The standard method for odour assessment involves measuring the concentration through dynamic olfactometry according with SR EN 13725:2003, a very complex method that requires specialized working staff and expensive equipment.

The paper presents an indirect method for odour assessment in the ambient air, based on monitoring the process and meteorological data - Predictive Emission Monitoring Systems (PEMS) and it is applied to a livestock farm. Using the multiple regression analysis of the monitoring data for the most important specific technological and meteorological parameters it can be developed a mathematical model that could be used for the calculation of odour concentration in air, without the necessity of direct measurement, after the initial step. For the case study presented in the paper, the distance between the slurry lagoon was identified as a significant statistical parameter that can determine in a proportion of $72 \%$ the concentration of odour in the ambient air nearby the farm; the margin of error for odour concentration assessment, according to the model validation tests, is $\pm 8 \%$, acceptable value for an estimation method by mathematical modelling.

Keywords: odour, dynamic olfactometry, multiple regression method, intensive livestock farming

Odour can be defined as sensations resulting from the interaction of volatile chemical species inhaled through nose, making contact with the olfactory area and registering in the brain [1]; in this context, the standardized method for odour determination, the method based on dynamic olfactometry [2-4] uses the human nose, respectively a group of odour assessor connected to an olfactometer - a performant system that dilutes, present the samples to the human assessors, and does all the calculations using a data processing software. An automatic alternative based on electrochemical cells is represented by the electronical nose, used mainly in comparative studies [5]. Even though the direct methods are preferred, in the case when these analyses are very complex, involves very high costs or impracticable conditions,

\section{EXPERIMENTAL PART}

Location. The case study was conducted at a livestock farm operating at maximum capacity, which, according to Order no. 994/2018 [12] indirect methods can be used, methods based on statistical analysis of the parameters values that are correlated with the level of odour emission. In this regard, the use of statistical correlation and regression methods have been applied in various activity, including environmental protection. [6-10].

The paper presents an indirect method for odour assessment based on the monitoring of process, meteorological and geographical parameters Predictive Emission Monitoring Systems [11] applied to a livestock farm. Using the multiple regression analysis applied to specific monitoring parameters data it is intended to obtain a mathematical model that can be used for the odour concentration in air estimation, without direct measurement, except the initial phase.

requires a $1500 \mathrm{~m}$ sanitary protection area. The farm is in a hilly area, in the immediate vicinity of a locality, characterized by winds in the 
direction of $\mathrm{NV}$, as shown by the graphical expression of the wind rose (Figure 1).

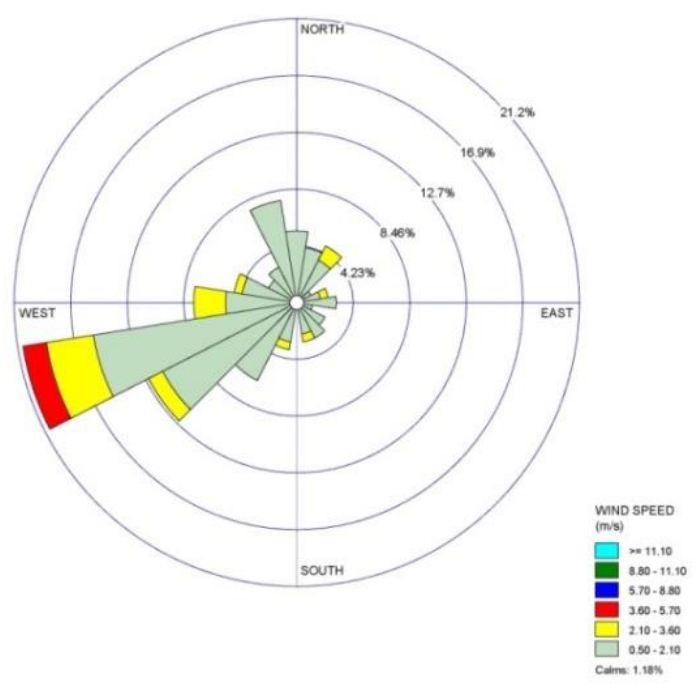

Fig. 1. Wind rose of the area

The very small distance, sometimes under $100 \mathrm{~m}$ from houses, determined over the years some problems due to the air pollution with $\mathrm{NH} 3$, $\mathrm{H} 2 \mathrm{~S}$, and odours largely due to the activities carried out on the farm but also to the noncompliance with the sanitary protection area. Technological processes carried out on the farm meet the requirements of the BAT Conclusions [13], both in terms of the application of the best technologies and also regarding the methods for reducing pollutant emissions in the air. Thus, animal feeding and shelter ventilation systems are automated, the ventilation rate being set according to the temperature and humidity parameters of the shelter to ensure optimal animal development conditions. The slurry is automatically transferred to pre-sealed lagoons that prevent soil and ground infiltration and are covered with sealed geomembranes where they are enzymatically treated to reduce pollutant/odour emissions in the air.

Materials and Methods. The evaluation method is based on the statistical correlation and multiple regression analysis applied to the data series obtained by monitoring the odour concentration, the main specific odorous pollutants $\left(\mathrm{NH}_{3}\right.$ and $\left.\mathrm{H}_{2} \mathrm{~S}\right)$ and the technological / geographic parameters and involves the following steps: i) identification the main sources of odour emission and their specific parameters, ii) monitoring of the identified parameters and of the odour concentration, iii) correlation and multiple regression analysis applied to the data series obtained by monitoring, iv) obtaining the equation of the mathematical model and its validation by direct measurements and by the mathematical modelling of the odour dispersion in the air.

Based on the analysis of technological processes from a livestock farm and the main BAT techniques [13] to reduce the odour level but also on the specific conditions of the farm in which the case study was conducted, three potential sources of odour pollution and strong smelling compounds have been identified: ventilation openings for animal shelters $\left(\mathrm{NH}_{3}\right.$, odour), the slurry transfer system $\left(\mathrm{NH}_{3}, \mathrm{H}_{2} \mathrm{~S}\right.$, odour) and the lagoons for storage / treatment of slurry $\left(\mathrm{NH}_{3}, \mathrm{H}_{2} \mathrm{~S}\right.$, smell) to which are added the sources of diffuse emissions. In these conditions the parameters that can characterize the emissions of odour and strong smelling specific compounds, $\mathrm{NH}_{3}$ and $\mathrm{H}_{2} \mathrm{~S}$, which were taken into account for the mathematical model development are: i) ventilation rate, expressed in $\%$ from the maximum capacity (vent-cap), ii) distance to shelters, $\mathrm{m}$ (dist), iii) distance to lagoons, $\mathrm{m}$ (dist), iv) wind direction, expressed in degrees $\mathrm{N}$ (dir-vant), $\mathrm{v}$ ) wind speed, $\mathrm{m} / \mathrm{s}$ (vitvant), vi) atmospheric temperature, ${ }^{0} \mathrm{C}$ (temp), (vii) atmospheric humidity, \% (RH) and viii) the concentration of $\mathrm{NH}_{3}$ and $\mathrm{H}_{2} \mathrm{~S}$ in air (in the case of odour calculation) in $\mu \mathrm{g} / \mathrm{m}^{3}$ or $\mathrm{mg} / \mathrm{m}^{3}$. For concentration of $\mathrm{NH}_{3}$ and $\mathrm{H}_{2} \mathrm{~S}$ determination, Horiba automatic analysers were used, with detection limits of 5 ppbv for $\mathrm{NH}_{3}$ and 2 ppbv for $\mathrm{H}_{2} \mathrm{~S}$. The odour analyzis was done following the dynamic olfactometry method according to 
SR EN 13725:2003 using a Odournet T08 dynamic olfactometer, developed by Odournet GMBH, Germany. Meteorological parameters were monitored using a MetPack Wind Sonic Portable Weather Station. For the statistical interpretation of the data - Pearson correlation and multiple regression analysis - the SPSS 20.0 (Statistical Package for Social Sciences, version 20.0) software was used. The correlation analysis provides information regarding the intensity and direction of the statistical link between two or more variables without necessarily involving a causal link between them. In the case study Pearson correlation was used, whose coefficient ( $r$ ) can take values in the range $[-1,+1]$; the closer is the value of the $r$ coefficient to \pm 1 , the better is the correlation between the two analyzed parameters. To assess the statistical significance of the correlation coefficient and the regression coefficients, the $p$ value - the probability that the value of the correlation coefficient is equal to zero (the null hypothesis) - is used; if the probability is less than the significance level (ex. $\mathrm{p}<0.05$ for a confidence level of 95\%), then the correlation coefficient is statistically significant. Statistical

\section{RESULTS AND DISCUSSION}

Starting from the actual conditions on the site, 9 points were identified outside the farm enclosure at different distances from animal shelters and lagoons for slurry manure handling and storage, around the site; at each point measurements of the concentration were made for $\mathrm{NH}_{3}, \mathrm{H}_{2} \mathrm{~S}$, odour and weather parameters, and the results of the measurements are found in Table 1. Analyzing the results of the measurements and compared with the limit values for the concentration of $\mathrm{H}_{2} \mathrm{~S}$ and $\mathrm{NH}_{3}$ in the air [14] it can see that in all 9 points the concentration exceed the limit values for short-term measurements $\left(0.015 \mathrm{mg} / \mathrm{m}^{3}\right.$ for $\mathrm{H}_{2} \mathrm{~S}$ and 0.300 correlation is always the first step in predictive studies preceding regression analysis.

The regression represents the process by which it can estimate the value of the dependent variable based on the values of the predictor variables and the mathematical relationship expressing their interdependence. Such an estimate is, in fact, a prediction. In this case study, the multiple regression was used, which basically relies on the same fundamental concepts as simple linear regression, but must deal with the specific problems of a multivariate model. The multiple regression equation (Ec. 1) is similar to the simple regression equation, applied to several predictors:

$$
Y=a+b_{1} x_{1} \ldots \ldots+b_{k} x_{k}
$$

in which:

$x_{1} \ldots x_{k}=$ values of the $k$ predictor variables

$a=$ ordinate to origin

$b_{1} \ldots b_{k}=$ regression coefficients corresponding to the $k$ predictor variables

$Y=$ estimate values for the criterion variable (dependent)

$\mathrm{mg} / \mathrm{m}^{3}$ for $\mathrm{NH}_{3}$ ); it should be noted that these points are located inside the sanitary protection area (at distances of $80-440 \mathrm{~m}$ from the farm), demonstrating once again the necessity of regard the sanitary protection zones imposed by Order no. 994/2018 [12].

In this case the $1500 \mathrm{~m}$ sanitary protection area is not respected, with housing reaching in some cases $100 \mathrm{~m}$ from animal shelters. With regard to odour concentrations, for which limit values are not set in the ambient air, it finds values that fall within the normal range for these types of activities, taking into account the small distance from the emission sources.

Table 1. Values of parameters monitored in the livestock farm

\begin{tabular}{|c|c|c|c|c|c|c|c|c|c|c|c|}
\hline Point & Location & $\begin{array}{c}\mathrm{H}_{2} \mathrm{~S}, \\
\mu \mathrm{g} / \mathrm{m}^{3}\end{array}$ & $\begin{array}{c}\mathrm{NH}_{3}, \\
\mathrm{mg} / \mathrm{m}^{3}\end{array}$ & $\begin{array}{c}\text { Odour, } \\
\mathrm{ou} / \mathrm{m}^{3}\end{array}$ & $\begin{array}{c}\mathrm{Temp}, \\
{ }^{0} \mathrm{C}\end{array}$ & $\begin{array}{c}\mathrm{RH}, \\
\%\end{array}$ & $\begin{array}{c}\text { vent- } \\
\text { cap, } \%\end{array}$ & $\begin{array}{c}\text { Dist, } \\
\mathrm{m}\end{array}$ & $\begin{array}{c}\text { dist-lag, } \\
\mathrm{m}\end{array}$ & $\begin{array}{c}\text { dir-vant, } \\
\text { grade }\end{array}$ & $\begin{array}{c}\text { vit-vant, } \\
\mathrm{m} / \mathrm{s}\end{array}$ \\
\hline 0 & 1 & 2 & 3 & 4 & 5 & 6 & 7 & 8 & 9 & 10 & 11 \\
\hline 1 & Farm gate & 35.40 & 1.30 & 16.00 & 17.00 & 56.00 & 50.00 & 310.00 & 600.00 & 104.00 & 0.60 \\
\hline 2 & $\begin{array}{c}\text { Close to lagoon and } \\
\text { slurry distribution area }\end{array}$ & 69.50 & 3.90 & 31.00 & 21.00 & 44.00 & 50.00 & 290.00 & .00 & 150.00 & 0.70 \\
\hline 3 & $\begin{array}{c}25 \mathrm{~m} \text { from the pt 2. to } \\
\text { farm }\end{array}$ & 38.60 & 5.60 & 47.00 & 22.00 & 41.00 & 64.00 & 240.00 & 90.00 & 163.00 & 1.70 \\
\hline 4 & $25 \mathrm{~m}$ from pt 1. to N & 39.50 & 1.51 & 19.00 & 23.00 & 41.00 & 64.00 & 370.00 & 660.00 & 220.00 & 1.90 \\
\hline 5 & On the road (house) & 33.20 & 10.20 & 4.40 & 23.00 & 41.00 & 70.00 & 160.00 & 600.00 & 211.00 & 2.19 \\
\hline
\end{tabular}




\begin{tabular}{|c|c|c|c|c|c|c|c|c|c|c|c|}
\hline 0 & 1 & 2 & 3 & 4 & 5 & 6 & 7 & 8 & 9 & 10 & 11 \\
\hline 6 & On the road (pension) & 35.60 & 3.98 & 8.00 & 23.00 & 41.00 & 95.00 & 440.00 & 810.00 & 213.00 & 1.35 \\
\hline 7 & $\begin{array}{c}\text { In the farm, close to the } \\
\text { monitoring system }\end{array}$ & 36.30 & 13.06 & 18.00 & 23.00 & 42.00 & 100.00 & 80.00 & 520.00 & 171.00 & 0.70 \\
\hline CMA (30 min) & 15 & 0.300 & & & & & & & & \\
\hline Average & 41.15 & 5.65 & 20.48 & 21.71 & 43.71 & 70.42 & 270.00 & 468.57 & 176.00 & 1.305 \\
\hline Standard deviation & 4.789 & 1.672 & 5.470 & .837 & 2.089 & 7.55 & 46.291 & 114.775 & 15.87 & .245 \\
\hline$\quad$ Median & 36.30 & 3.98 & 18.00 & 23.00 & 41.00 & 64.00 & 290.00 & 600.00 & 171.00 & 1.35 \\
\hline$\quad$ Minimum value & 33.20 & 1.30 & 4.40 & 17.00 & 41.00 & 50.00 & 80.00 & .00 & 104.00 & 0.60 \\
\hline$\quad$ Maximum value & 69.50 & 13.06 & 47.00 & 23.00 & 56.00 & 100.00 & 440.00 & 810.00 & 220.00 & 2.19 \\
\hline 8 & 30m from pt. 2 & 46.5 & 3.21 & 29 & 18 & 54 & 35 & 220 & 200 & 110 & 0.9 \\
\hline 9 & $\begin{array}{c}\text { On the road, close to the } \\
\text { office }\end{array}$ & 42.4 & 10.1 & 24 & 20 & 46 & 80 & 120 & 410 & 165 & 1.2 \\
\hline
\end{tabular}

\section{Statistical interpretation of data}

First step in the statistical interpretation of data was the Pearson correlation analysis, whose results are found in Table 2 (the Pearson correlation coefficients, $r$ ) reveals for the interest indicators, odour, $\mathrm{NH}_{3}$ and $\mathrm{H}_{2} \mathrm{~S}$ a series of very good and good correlations with some of the monitored parameters, as follows:

$>$ in the case of the odour concentration a very good inverse correlation with the distance from the lagoon $\left(r_{\text {odour }}=-0.847\right)$ and moderate, direct correlation with the $\mathrm{H}_{2} \mathrm{~S}$ concentration $\left(r_{\text {odour }}=0.425\right)$ is observed;

$>$ in the case of $\mathrm{H}_{2} \mathrm{~S}$ concentration a very good inverse correlation with the distance to the lagoon $\left(r_{H 2 S}=-0.718\right)$, and also moderate correlations with the ventilation capacity of the shelters $\left(r_{H 2 S}=-0.468\right)$ and odour concentration $\left(r_{\text {odour }}=0.425\right)$;

for the concentration of $\mathrm{NH}_{3}$ we can observe a very good inverse correlation with the distance from the animal shelters $(\mathrm{r}=$ $0.865)$, a good correlation with the ventilation capacity of the shelters $\left(\mathrm{r}_{\mathrm{H} 2 \mathrm{~S}}=0.618\right)$ and a moderate one with the atmospheric temperature and humidity.

Table 2. The values of the Pearson correlation coefficients, $r$

\begin{tabular}{|c|cccccccccc|}
\hline & odour & dist & dist-lag & dir-vant & vit-vant & temp & RH & vent-cap & H2S & NH3 \\
\hline odour & 1.000 & & & & & & & & & \\
dist & -.075 & 1.000 & & & & & & & & \\
dist-lag & -.847 & .270 & 1.000 & & & & & & & \\
dir-vant & -.376 & .155 & .432 & 1.000 & & & & & & \\
vit-vant & -.123 & .068 & .216 & .754 & 1.000 & & & & & \\
temp & -.107 & -.154 & .131 & .891 & .586 & 1.000 & & & & \\
RH & -.080 & .116 & .061 & -.835 & -.605 & -.974 & 1.000 & & & \\
vent-cap & -.379 & -.209 & .493 & .506 & .042 & .640 & -.510 & 1.000 & & \\
H2S & .425 & .118 & -.718 & -.257 & -.394 & -.116 & -.015 & -.468 & 1.000 & \\
NH3 & -.169 & -.865 & -.014 & .213 & .065 & .504 & -.430 & .618 & -.239 & 1.000 \\
\hline
\end{tabular}

Colour legend:

\begin{tabular}{|l|l|l|l|l|l|}
\hline Colour & & & & & \\
\hline Correlation significance & very week & week & moderate & good & very good \\
\hline
\end{tabular}

Under these conditions, the results of the Pearson correlation analysis provide the first indices for predictor variables with significance for the value of the dependent variable (odour concentration). Once a correlation between the variables is established, the statistical regression method is used to establish the mathematical relationship. In our case, multiple regression, the Forward method, was applied to the monitoring data series obtained in the first 7 measurement points (Table 1), including the concentrations of $\mathrm{NH}_{3}$ and $\mathrm{H}_{2} \mathrm{~S}$; points 8 and 9 were used to validate the mathematical model.

The results of multiple regression (Table 3 ) for odour concentration as a dependent variable eliminate as statistically insignificant all variables from the equation, except the distance from the lagoon, the only statistically significant 
variable $($ Sig. $=0.016)$.

Table 3. The results of multiple regression analysis for odour concentration.

Model Summary ${ }^{b}$

\begin{tabular}{|c|c|c|c|c|c|c|c|c|c|}
\hline \multirow[t]{2}{*}{ Model } & \multirow[t]{2}{*}{$\mathrm{R}$} & \multirow{2}{*}{$\begin{array}{c}\mathrm{R} \\
\text { Square }\end{array}$} & \multirow{2}{*}{$\begin{array}{l}\text { Adjusted R } \\
\text { Square }\end{array}$} & \multirow{2}{*}{$\begin{array}{l}\text { Std. Error of } \\
\text { the Estimate }\end{array}$} & \multicolumn{5}{|c|}{ Change Statistics } \\
\hline & & & & & $\begin{array}{l}\text { R Square } \\
\text { Change }\end{array}$ & F Change & df1 & df 2 & $\begin{array}{c}\text { Sig. F } \\
\text { Change }\end{array}$ \\
\hline 1 & $.847^{\mathrm{a}}$ & .718 & .662 & 8.41942 & .718 & 12.728 & 1 & 5 & .016 \\
\hline
\end{tabular}

a. Predictors: (Constant), dist-lag

b. Dependent Variable: odour

Coefficients $^{\mathbf{a}}$

\begin{tabular}{|c|c|c|c|c|c|c|c|}
\hline \multirow[t]{2}{*}{ Model } & \multicolumn{2}{|c|}{ Unstandardized Coefficients } & Standardized & \multirow[t]{2}{*}{$\mathrm{T}$} & \multirow[t]{2}{*}{ Sig. } & \multicolumn{2}{|c|}{ Collinearity Statistics } \\
\hline & $\mathrm{B}$ & Std. Error & Beta & & & Tolerance & VIF \\
\hline (Constant) & 39.408 & 6.185 & & 6.371 & .001 & & \\
\hline dist-lag & -.040 & .011 & -.847 & -3.568 & .016 & 1.000 & 1.000 \\
\hline
\end{tabular}

a. Dependent Variable: odour

\begin{tabular}{|c|c|c|c|c|c|c|c|c|}
\hline \multicolumn{9}{|c|}{ Excluded Variables $^{\mathrm{a}}$} \\
\hline \multirow{2}{*}{\multicolumn{2}{|c|}{ Model }} & \multirow[t]{2}{*}{ Beta In } & \multirow[t]{2}{*}{$\mathrm{t}$} & \multirow[t]{2}{*}{ Sig. } & \multirow{2}{*}{$\begin{array}{c}\text { Partial } \\
\text { Correlation }\end{array}$} & \multicolumn{3}{|c|}{ Collinearity Statistics } \\
\hline & & & & & & Tolerance & VIF & $\begin{array}{l}\text { Minimum } \\
\text { Tolerance }\end{array}$ \\
\hline \multirow{8}{*}{1} & dist & $.166^{\mathrm{b}}$ & .631 & .562 & .301 & .927 & 1.078 & .927 \\
\hline & dir-vant & $-.013^{\mathrm{b}}$ & -.044 & .967 & -.022 & .814 & 1.229 & .814 \\
\hline & vit-vant & $.064^{\mathrm{b}}$ & .236 & .825 & .117 & .953 & 1.049 & .953 \\
\hline & temp & $.003^{\mathrm{b}}$ & .013 & .990 & .007 & .983 & 1.017 & .983 \\
\hline & $\mathrm{RH}$ & $-.028^{\mathrm{b}}$ & -.105 & .922 & -.052 & .996 & 1.004 & .996 \\
\hline & vent-cap & $.051^{\mathrm{b}}$ & .168 & .875 & .084 & .757 & 1.321 & .757 \\
\hline & $\mathrm{H} 2 \mathrm{~S}$ & $-.378^{b}$ & -1.141 & .317 & -.496 & .484 & 2.064 & .484 \\
\hline & $\mathrm{NH} 3$ & $-.181^{b}$ & -.725 & .509 & -.341 & 1.000 & 1.000 & 1.000 \\
\hline
\end{tabular}

a. Dependent Variable: odour

b. Predictors in the Model: (Constant), dist-lag

The value of $\mathrm{R}^{2}=0.718$ indicates that this variable determines $71.8 \%$ of the odour concentration in the analyzed area. We mention that these results apply only to the conditions specific to the period in which the measurements and data sets were used.

Applying the same procedure in the case of $\mathrm{H}_{2} \mathrm{~S}$, similar results have been obtained, demonstrating that odour and $\mathrm{H}_{2} \mathrm{~S}$ emissions are from the same source, i.e. the lagoon in which the slurry effluent is discharged, the only parameter with statistical significance. In this case, however, this parameter characterizes the $\mathrm{H}_{2} \mathrm{~S}$ emission only in a proportion of $51.6 \%$. In the case of $\mathrm{NH}_{3}$ concentration, the results of the multiple regression analysis reveal two statistically significant parameters, the distance from the animal shelters and the ventilation rate, which together account for $94.8 \%$ of the emission.

The equations of the mathematical models for the three indicators and statistically significant parameters can be found in Table 4 . 
Table 4. Equations of mathematical models for estimating odour concentration, $\mathrm{NH}_{3}$ and $\mathrm{H}_{2} \mathrm{~S}$

\begin{tabular}{|c|c|c|}
\hline Indicator & Statistically significant indicators & Equation of the mathematical model \\
\hline \multirow[t]{3}{*}{ Odour } & - distance from the lagoon, $\mathrm{m}$ (dist-lag) & $Y=39.408-0.04 x$ \\
\hline & \multirow{4}{*}{ - distance from the lagoon, m (dist-lag) } & $x=$ distance from the lagoon, $\mathrm{m}$ \\
\hline & & $Y=$ estimated value for the odour concentration, $\mathrm{ou}_{\mathrm{e}} / \mathrm{m}^{3}$ \\
\hline $\mathrm{H}_{2} \mathrm{~S}$ & & $Y=55.198-0.03 x$ \\
\hline \multirow{5}{*}{$\mathrm{NH}_{3}$} & & $\begin{array}{l}x=\text { distance from the lagoon, } \mathrm{m} \\
Y=\text { estimated value for the concentration of } \mathrm{H}_{2} \mathrm{~S}, \mathrm{ug} / \mathrm{m}^{3}\end{array}$ \\
\hline & \multirow{4}{*}{$\begin{array}{l}\text { - ventilation rate, } \% \text { from maximum } \\
\text { capacity (vent-cap) } \\
\text { - distance from the shelters, } \mathrm{m} \text { (dist) }\end{array}$} & $Y=6.037-0.028 *$ dist $+0.101 *$ vent. cap \\
\hline & & $x_{l}=$ distance from the shelter, $\mathrm{m}$ \\
\hline & & $x_{2}=$ ventilation rate,$\%$ \\
\hline & & $Y=$ estimated value for the concentration $\mathrm{NH}_{3}, \mathrm{mg} / \mathrm{m}^{3}$ \\
\hline
\end{tabular}

In order to validate the equations of the mathematical models, the data obtained in points 8 and 9 were used; the error margin for odour concentration assessment according to model validation tests is $-8 \%$, for $\mathrm{NH}_{3}-6 \%$, and for $\mathrm{H}_{2} \mathrm{~S}-15 \%$, acceptable for an estimation method by mathematical modelling. Based on the mathematical equations developed for $\mathrm{H}_{2} \mathrm{~S}, \mathrm{NH}_{3}$ and odour, the concentrations of these pollutants can be calculated at any point on the site starting from the statistically significant parameters, respectively the distance from the lagoon for $\mathrm{H}_{2} \mathrm{~S}$ and odour and the distance from the shelter and ventilation rate for $\mathrm{NH}_{3}$. Thus, the minimum distances from the animal shelters for $\mathrm{NH}_{3}$ and from lagoon in the case of $\mathrm{H}_{2} \mathrm{~S}$ and odour were calculated that should be respected in order not to exceed the limit values in the legislation; for $\mathrm{H}_{2} \mathrm{~S}$ the estimated minimum distance from the lagoon is $1340 \mathrm{~m}$ and for $\mathrm{NH}_{3}$, for a maximum ventilation rate of $100 \%$, the distance from shelters must be at least $580 \mathrm{~m}$; in the case of odour, at an estimated distance of $960 \mathrm{~m}$ from the lagoon, the odour concentration would be below the theoretical threshold of odour perception (the odour concentration perceived by $50 \%$ of the members of a panel constituted according to SR EN $13725: 2003)$ of $1 \mathrm{ou} / \mathrm{m}^{3}$. Considering the value of the Maximum Allowable Concentration for $\mathrm{H}_{2} \mathrm{~S}\left(15 \mu \mathrm{g} / \mathrm{m}^{3}\right)$ it can be concluded that at a distance of at least $1340 \mathrm{~m}$ from the lagoon the concentration of $\mathrm{H}_{2} \mathrm{~S}$ is below the limit value, i.e. if the sanitary protection zone is respected the concentration of $\mathrm{H}_{2} \mathrm{~S}$ in sensitive areas would fall within the limit values imposed by environmental legislation in force [14]. The same applies to the odour and $\mathrm{NH}_{3}$ concentration.

\section{CONCLUSION}

Starting from the results obtained in the case study, we find once again a high level of chemical pollution $\left(\mathrm{NH}_{3}\right.$ and $\left.\mathrm{H}_{2} \mathrm{~S}\right)$ and odour generated by the livestock farm activities, but also the need to comply with the requirements of the regulations in force regarding the sanitary protection areas related to these farms, to ensure comfort and reduce the effect on the health of the population.

The indirect method of assessing the concentration of odour, $\mathrm{NH}_{3}$ and $\mathrm{H}_{2} \mathrm{~S}$ based on the analysis of the data series from the monitoring of the technological/geographic parameters through the multiple regression method is applicable to this type of activity; the method allows the estimation of odour, $\mathrm{NH}_{3}$ and $\mathrm{H}_{2} \mathrm{~S}$ concentration at any point on the site using mathematical relationships resulting from multiple regression analysis with an assessment error margin of $-8 \%$ for odour, $-6 \%$ for $\mathrm{NH}_{3}$ and $-15 \%$ for $\mathrm{H}_{2} \mathrm{~S}$, acceptable values for an estimation method by mathematical modelling. Using these relationships, the minimum values of the influence parameters on $\mathrm{H}_{2} \mathrm{~S}, \mathrm{NH}_{3}$ and odour emission (lagoon distance, shelter distance at an $100 \%$ ventilation rate) can be calculated for which the concentration of these indicators in air reaches the maximum concentration value admitted.

For the case study, the following results were obtained:

$>$ for $\mathrm{H}_{2} \mathrm{~S}$ the minimum distance to the lagoon: $1340 \mathrm{~m}$;

$>$ in the case of $\mathrm{NH}_{3}$, for the maximum ventilation rate $(100 \%)$ distance to: minimum $580 \mathrm{~m}$;

$>$ in case of odour at a distance of $960 \mathrm{~m}$ from the lagoon, the odour concentration 
is below $1 \mathrm{ou} / \mathrm{m}^{3}$ - the theoretical sanitary protection areas these concentrations threshold of odour perception;

exceed the limit values for sensitive areas [14] in We can appreciate that, for the case studied, outside the $1500 \mathrm{~m}$ of the sanitary protection area, the estimated odour concentrations, $\mathrm{NH}_{3}$ and $\mathrm{H}_{2} \mathrm{~S}$ are below the limit values; inside the the case of the settlements that do not respect the minimum distance from the farm imposed by the legislation.

ACKNOWLEDGEMENTS. The authors acknowledge the financial support offered by The National Research Nucleu Program through Project 20N/2019; the authors would like to thank all those who contributed to this study, too.

\section{REFERENCES}

1. GREGORY, L., KENDALL, D., BARNARD, N., J AirPollut Control Assoc, 19, no. 2, 1969, p. 91.

2. SR EN 13725:2003 Air quality. Determination of odour concentration by dynamic olfactometry.

3. VASile, A., DANCiUlescu, V., TANASE, G., KIM, L., DEDIU, V., Rev. Chim. (Bucharest), 68, no. 8, 2017, p. 1749.

4. JIANG, J., COFFEY, P., TOOHEY, B., J Air Waste Manag Assoc, 56, 2006, p. 675.

5. HUDON, G., GUY, C., HERMIA, J., J Air Waste Manag Assoc, 50, 2000, p. 1750.

6. MORRISON, S., FORDYCE, F.M., SCOTT, E.M., Environ Geochem Health, 36, 2014, p. 319.

7. YOO, J.M., LEE, Y.R., KIM, D., JEONG, M.J., STOCKWELL, W.R., KUNDU, P.K., OH, S.M., SHIN, D.B., LEE, S.J., Atmos Environ, 82, 2014, p. 226.

8. KLIUCININKAS, L., KRUGLY, E., STASIULAITIENE, I., RADZIUNIENE, I., PRASAUSKAS, T., JONUSAS, A., KAUNELIENE, V., MARTUZEVICIUS, D., Atmos Environ, 97, 2014, p. 83.

9. BUCUR E., DANET, A.F., LEHR, C.B., LEHR, E., NITA-LAZAR, M., J Air Waste Manag Assoc., 67, no. 4, 2017, p. 391.

10. DANCIULESCU, V., BUCUR, E., PASCU, L.F., VASILE, A., BRATU, M., J Environ Prot Ecol., 16, no. 3, 2015, p. 815.

11. http://eippcb.jrc.ec.europa.eu/reference/ - JRC Reference Report on Monitoring of Emissions to Air and Water from IED installations, 2017.

12. Ordinul nr. 994/2018 pentru modificarea si completarea Normelor de igiena si sanatate publica privind mediul de viata al populatiei, aprobate prin Ordinul ministerului sanatatii nr. $119 / 2014$.

13. Commission Implementing Decision (EU) 2017/302 of 15 February 2017 establishing best available techniques (BAT) conclusions, under Directive 2010/75/EU of the European Parliament and of the Council, for the intensive rearing of poultry or pigs.

14. STAS 12574-87. Aer din zonele protejate. Conditii de calitate (in Romanian). 